\section{Bur Seeding Rate Effects on Turf-type Buffalograss Establishment}

R.C. Shearman ${ }^{1}$, H. Budak ${ }^{2}$, S. Severmutlu ${ }^{3}$, and

R.E. Gaussoin ${ }^{4}$

AdDitional INDEX wORDs. Buchloë dactyloides, turfgrass

SumMary. Little or no research information exists in the literature regarding recommended seeding rates of improved turf-type buffalograss (Bucbloë dactyloides) cultivars, like 'Bowie'. This research was conducted to determine the effect of bur seeding rate on turfgrass establishment of 'Bowie' buffalograss. Two experiments were initiated on 21 July 2002 on diverse sites at the John Seaton Anderson Turfgrass Research Facility located near Mead, Nebr. Bur seeding rate effects on turfgrass quality, shoot density and cover, and seedling density were evaluated during the 2002 and 2003 growing seasons. Burs were seeded at $2.5,5,10,20$, and 40 $\mathrm{g} \cdot \mathrm{m}^{-2}(0.51,1.0,2.0,4.1$, and 8.2 $\mathrm{lb} / 1000 \mathrm{ft}^{2}$ ) of pure live seed (PLS). Turfgrass quality ratings increased linearly with bur seeding rate during the first growing season. However, by early in the second growing season, the response was quadratic with little or no difference in quality between 10 and $40 \mathrm{~g} \cdot \mathrm{m}^{-2}$. Turfgrass cover ratings responded in a similar manner to the quality ratings. Buffalograss is reported to establish slowly, taking more than one growing season to establish an acceptable level. In this study, 'Bowie', a turf-type cultivar, had acceptable turfgrass quality $(\geq 5.0)$ and cover $(\geq 75 \%)$ ratings by 3 months at bur seeding rates of 5 to $40 \mathrm{~g} \cdot \mathrm{m}^{-2}$ of PLS, and acceptable quality and cover ratings were obtained at slightly

Department of Agronomy and Horticulture, University of Nebraska-Lincoln, Lincoln, NE 68583-0724

A contribution of the University of Nebraska Agricultural Research Division, Lincoln, NE 68583. Journal Series No. 14540.

${ }^{1}$ To whom reprint requests should be directed. E-mail address: rshearmanl@unl.edu

${ }^{2}$ Buffalograss Breeding Program Coordinator.

${ }^{3}$ Graduate Research Assistant.

${ }^{4}$ Professor. over 1 month at rates of 20 to 40 $\mathrm{g} \cdot \mathrm{m}^{-2}$. These results indicate that bur seeding rates of 20 to $40 \mathrm{~g} \cdot \mathrm{m}^{-2}$ are advisable where rapid establishment of turf-type buffalograss is desired, and rates as low as $5 \mathrm{~g} \cdot \mathrm{m}^{-2}$ can be used when establishment within two growing seasons is deemed reasonable.

$\mathrm{B}$ uffalograss is native to the Great Plains of North America, ranging from Mexico to Canada (Beetle, 1950; Reeder, 1971). It is perennial, stoloniferous, sod forming, and predominantly dioecious (Riordan etal., 1993; Stubbendiecket al., 1992). The female inflorescence produces burs containing three to five caryopses that are located in the canopy of the buffalograss sward (Quinn, 1987; Riordan et al, 1993; Wenger, 1940).

Burs are commonly used to seed buffalograss stands (Beard, 1973). Historically, establishment of buffalograss has been reported to be slow, taking two or more growing seasons to establish an acceptable stand (Gaitan-Gaitan et al., 1998; Hauser, 1986; Launchbaugh and Owensby, 1970; Riordan et al., 1997; Savage, 1934; Wu et al., 1989). Ahring and Todd (1977) found growth inhibitors located in the bur that reduced germination. Researchers have tried various methods of increasing germination by reducing the impact of these growth inhibitors on establishment of seeded burs, including acid and chemical treatments, soaking and chilling treatments, and mechanical removal of the caryopses from the bur (Ahring and Todd, 1977; Gaitan-Gaitan et al., 1998; Hickey et al., 1983; Riordan et al., 1997; Wenger, 1943). Gaitan-Gaitan et al. (1998) and Riordan et al. (1997) found that deburred buffalograss seed (caryopses) resulted in more rapid establishment compared to burs, but the deburring procedure is expensive and not readily available throughout the industry (Harivandi and Wu, 1995). Therefore, the majority of buffalograss stands are seeded with burs that are chemically treated and chilled (Fry, 1995). Seeding is the most cost effective method for establishment of large areas, and seed is more readily available to turfgrass managers than sod, sprigs, or plugs (Fry, 1995; Wu et al., 1989).

Very little information is available in the turfgrass literature regarding bur seeding rates, with the exception 
of extension publication recommendations, which often conflict with one another (Gaitan-Gaitan et al., 1999). Recommendations for buffalograss bur seeding rates range from 2.5 to $10 \mathrm{~g} \cdot \mathrm{m}^{-2}$ (Beetle, 1950; Keeley and Fagerness, 2001; Riordan, 1991; Wenger, 1943) and rates as high as 25 to $30 \mathrm{~g} \cdot \mathrm{m}^{-2}\left(5.1\right.$ to $\left.6.1 \mathrm{lb} / 1000 \mathrm{ft}^{2}\right)$ have been recommended where rapid establishment is desired (Duble, 1989; McCarty, 1995). In addition, these seeding rate recommendations were derived mostly from non-turf-type cultivars. For example, Gaitan-Gaitan et al. (1999) worked with 'Texoka' and 'Comanche'; Riordan et al. (1997) worked with 'Hays'; and Wenger (1943) worked with an unnamed variety. None of these were especially bred and selected for turfgrass use.

This study was initiated to determine the effect of bur seeding rates of 'Bowie', an improved turf-type buffalograss, on turfgrass quality, shoot density, and cover.

\section{Materials and methods}

Two 'Bowie' buffalograss seeding rate experiments were conducted at diverse locations on the John Seaton Anderson Turfgrass Research Facility located near Mead, Nebr. Site A had a northern exposure and site B a southern, and the two sites were separated by a distance of $1.5 \mathrm{~km}$ ( 0.93 mile). The soil type for each location was a Tomek, silty-clay loam (fine, montmorillonitic mesic Typic Argiudoll). Soil phosphorus $(\mathrm{P})$ and potassium $(\mathrm{K})$ levels differed between the two sites. Site A had a P-level of $45 \mathrm{mg} \cdot \mathrm{L}^{-1}(\mathrm{ppm})$ and site $B$ had $62 \mathrm{mg} \cdot \mathrm{L}^{-1}$. Potassium levels were 385 and $534 \mathrm{mg} \cdot \mathrm{L}^{-1}$ for sites $\mathrm{A}$ and $\mathrm{B}$, respectively.

A randomized complete-block design with treatments replicated three times was used for each experiment. Bur seeding rate treatments were 2.5, $5,10,20$, and $40 \mathrm{~g} \cdot \mathrm{m}^{-2}$ of pure live seed. Treatment plot size was $2.1 \times$ $2.1 \mathrm{~m}(7 \mathrm{ft})$.

Both experiments were initiated on 19 July 2002. Treatments were hand seeded, raked to incorporate seed to a soil depth of $6 \mathrm{~mm}$ (0.24 inch), and rolled to firm the soil surface and enhance seed-soil contact. Starter fertilizer $(19 \mathrm{~N}-10.8 \mathrm{P}-4.9 \mathrm{~K})$ was applied over the seedbed at $5 \mathrm{~g} \cdot \mathrm{m}^{-2} \mathrm{~N}$. Irrigation was applied at $6 \mathrm{~mm}$ daily for the first 3 weeks, at $25 \mathrm{~mm}$ (1.0 inch) weekly for 4 weeks, and $25 \mathrm{~mm}$ monthly for the remainder of the study. If precipitation exceeded the scheduled irrigation amount, no irrigation was applied for that time period. The first mowing occurred when plants exceeded $75 \mathrm{~mm}$ (3.0 inches) and subsequent mowings were done weekly at $50 \mathrm{~mm}$ (2.0 inches) with clippings being returned. In the establishment year, only starter fertilizer was applied as previously described. In the second year, $10 \mathrm{~g} \cdot \mathrm{m}^{-2} \mathrm{~N}$ was applied from $44 \mathrm{~N}-0 \mathrm{P}-0 \mathrm{~K}$ with equal applications made on 16 June and 16 July 2003 No pesticides were applied during this study.

Seedling and shoot density counts were taken from 100-mm-diameter (3.9 inch) plugs. A $2.1 \times 2.1-\mathrm{m}$ frame, containing 49 grids of equal size, was constructed to fit the treatment plot. The frame was placed on the treatment plot each time counts were made, and five $100-\mathrm{mm}$-diameter plugs were taken randomly from each treatment plot. Plugs were returned to their original location after counting, and those locations were not used for future sampling. Turfgrass quality was rated monthly using a $1-9$ visual rating scale with 1 = poorest, $5=$ acceptable, and 9 = best. Turfgrass cover was rated monthly and was based on a visual rating scale of 0 to $100 \%$, with $0 \%=$ no turfgrass cover and $100 \%=$ total turfgrass groundcover. A rating of $75 \%$ was considered acceptable.

Data were collected during the 2002 and 2003 growing seasons. Analysis of variance (ANOVA) was performed on the data and means were separated using Fisher's protected least significant difference test $(P<0.05)$, when a significant F-test was detected (SAS Institute, 1999). A Hartley's F max test (Hartley, 1950) was used to test homogeneity of variance between the two experiments.

\section{Results and discussion}

The data from the first and second experiments of this study were combined because the F max test (Hartley, 1950) resulted in acceptance of the hypothesis of homogeneity of variance between the two trials. There were significant differences among seeding rates for turfgrass quality, seedling density, shoot density, and cover (Tables 1 and 2).

Turfgrass quality ratings increased linearly with increased bur seeding rate during the first growing season (Table
1). However, early in the second growing season the response was quadratic and there was little or no difference in quality ratings for seeding rates $\geq 10$ $\mathrm{g} \cdot \mathrm{m}^{-2}$ (Table 2 ). Seedling density was measured for 3 weeks after seeding. Density measurements were linear in response to seeding rates (Table 1). Seedling density at $40 \mathrm{~g} \cdot \mathrm{m}^{-2}$ was nearly 10 times the density measured at the $2.5 \mathrm{~g} \cdot \mathrm{m}^{-2}$ seeding rate by 3 weeks after seedling emergence, and was over 2.5 times that measured at $10 \mathrm{~g} \cdot \mathrm{m}^{-2}$. Gaitan-Gaitan et al. (1999) reported an increase in buffalograss plant numbers as bur seeding rates were increased from 8.9 to $22.7 \mathrm{~g} \cdot \mathrm{m}^{-2}$ ( 1.8 to $4.6 \mathrm{lb} / 1000 \mathrm{ft}^{2}$ ). Turfgrass cover followed the same trend as quality (Table 1 ). A cover rating $\geq 75 \%$ was considered adequate to provide cover minimizing weed encroachment and providing acceptable turfgrass quality. The $40 \mathrm{~g} \cdot \mathrm{m}^{-2}$ rate exceeded the $75 \%$ cover level by $33 \mathrm{~d}$ after seeding (DAS), and by 40 DAS the $20 \mathrm{~g} \cdot \mathrm{m}^{-2}$ rate also exceeded the acceptable level of cover. Falkenberg and Butler (1981) reported good initial cover from bur seeding rates of $19 \mathrm{~g} \cdot \mathrm{m}^{-2}\left(3.9 \mathrm{lb} / 1000 \mathrm{ft}^{2}\right)$ at Fort Collins, Colo. They concluded that only seeding rates between 19 and $27 \mathrm{~g} \cdot \mathrm{m}^{-2}(3.9$ and $5.5 \mathrm{lb} / 1000$ $\mathrm{ft}^{2}$ ) produced acceptable cover in the first growing season. Their research was not conducted with an improved, turf-type buffalograss.

In Kansas, Fry et al. (1993) reported $95 \%$ cover by 6 and 9 weeks after seeding with bur seeding rates of 15 and $5 \mathrm{~g} \cdot \mathrm{m}^{-2}\left(3.1\right.$ and $\left.1.0 \mathrm{lb} / 1000 \mathrm{ft}^{2}\right)$, respectively. In California, Harivandi et al. (1995) reported that seeding with caryopses at 7.5 and $10 \mathrm{~g} \cdot \mathrm{m}^{-2}$ ( 1.5 and $2.0 \mathrm{lb} / 1000 \mathrm{ft}^{2}$ ) produced acceptable stands more quickly than lower seeding rates. In this study, 61 DAS treatments $\geq 5 \mathrm{~g} \cdot \mathrm{m}^{-2}$ had acceptable cover ratings and the $2.5 \mathrm{~g} \cdot \mathrm{m}^{-2}$ rate was very close at $71 \%$. 'Bowie' was developed as a seeded, turf-type cultivar and it appears that it has vigorous establishment characteristic with the capability of developing an acceptable turfgrass cover in less than one growing season even at seeding rates as low as $5 \mathrm{~g} \cdot \mathrm{m}^{-2}$.

By 2003, turfgrass quality, shoot density, and cover were measured monthly from June through August (Table 2). There was a quadratic response for seeding rate effects on turfgrass quality and cover during 
Table 1. Seeding rate effects on 'Bowie' buffalograss turfgrass quality, shoot density, and cover ratings measured during the $\mathbf{2 0 0 2}$ growing season at the John Seaton Anderson Turfgrass Research Facility located near Mead, Nebr. Burs were seeded on 19 July 2002.

\begin{tabular}{|c|c|c|c|c|c|c|c|c|c|}
\hline \multirow{2}{*}{$\begin{array}{l}\text { Seeding rate } \\
\left(\mathrm{g} \cdot \mathrm{m}^{-2} \text { PLS }\right)\end{array}$} & \multicolumn{3}{|c|}{ Quality $^{\mathrm{y}}$} & \multicolumn{3}{|c|}{ Seedling density ${ }^{x}$} & \multicolumn{3}{|c|}{ Coverw } \\
\hline & 21 Aug. & 25 Sept. & 5 Oct. & 26 July & 2 Aug. & 9 Aug. & 21 Aug. & 28 Aug. & 18 Sept. \\
\hline 2.5 & $4.3 \mathrm{a}^{\mathrm{v}}$ & $4.3 \mathrm{a}$ & $4.7 \mathrm{a}$ & $18 \mathrm{a}$ & $23 \mathrm{a}$ & $23 \mathrm{a}$ & $10 \mathrm{a}$ & $23 \mathrm{a}$ & $71 \mathrm{a}$ \\
\hline 5 & $4.7 \mathrm{a}$ & $5.0 \mathrm{~b}$ & $5.6 \mathrm{~b}$ & 38 a & 39 a & $41 \mathrm{~b}$ & $27 \mathrm{~b}$ & $43 \mathrm{~b}$ & $80 \mathrm{~b}$ \\
\hline 10 & $6.0 \mathrm{~b}$ & $6.3 \mathrm{c}$ & $6.3 \mathrm{c}$ & $70 \mathrm{~b}$ & $69 \mathrm{~b}$ & $80 \mathrm{c}$ & $40 \mathrm{c}$ & $67 c$ & $83 \mathrm{~b}$ \\
\hline 20 & $6.7 \mathrm{c}$ & $7.3 \mathrm{~d}$ & $7.7 \mathrm{~d}$ & $113 c$ & $139 \mathrm{c}$ & $119 \mathrm{~d}$ & $57 \mathrm{~d}$ & $77 \mathrm{~d}$ & $90 \mathrm{c}$ \\
\hline 40 & $7.7 \mathrm{~d}$ & $8.0 \mathrm{e}$ & $8.7 \mathrm{e}$ & $180 \mathrm{~d}$ & $171 \mathrm{~d}$ & $216 \mathrm{e}$ & $77 \mathrm{e}$ & 89 e & $97 \mathrm{~d}$ \\
\hline Linear & * & * & * & * & * & * & * & * & * \\
\hline
\end{tabular}

Table 2. Seeding rate effects on 'Bowie' buffalograss turfgrass quality, shoot density, and cover ratings measured during the $\mathbf{2 0 0 3}$ growing season at the John Season Anderson Turfgrass Research Facility located near Mead, Nebr. Burs were seeded on 19 July 2002.

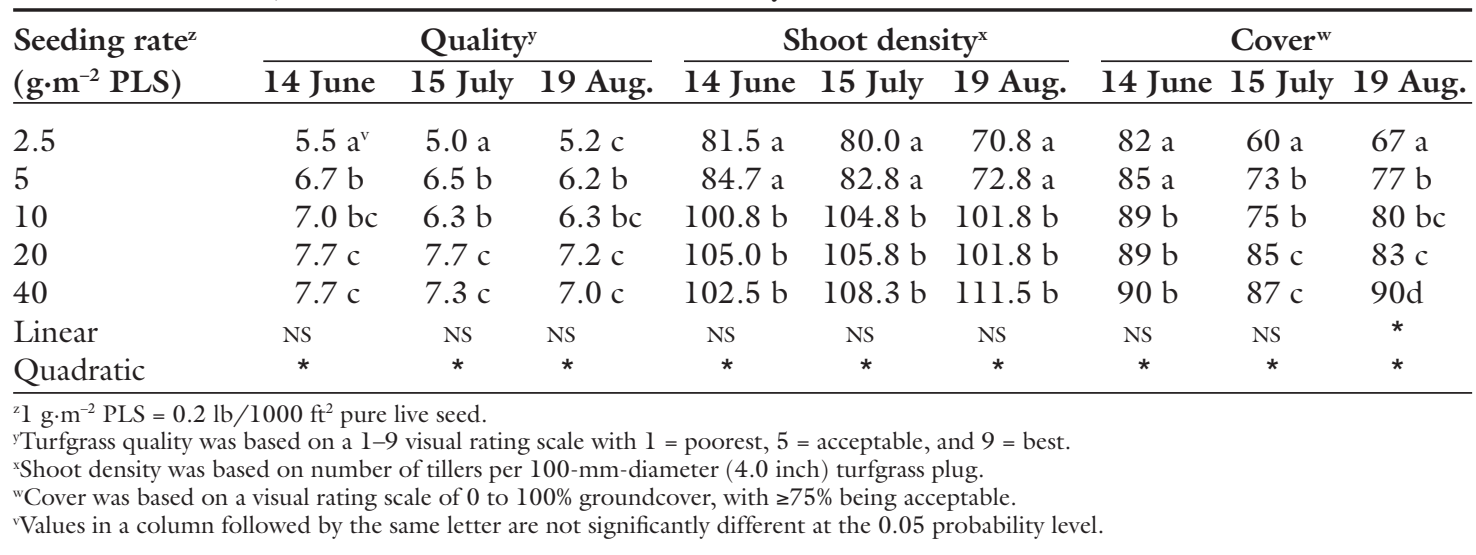

the second growing season. Turfgrass quality, shoot density, and cover did not differ between 10 and $40 \mathrm{~g} \cdot \mathrm{m}^{-2}$. Turfgrass quality ratings were acceptable $(\geq 5)$ for all treatments except the $2.5 \mathrm{~g} \cdot \mathrm{m}^{-2}$, although the low rate would have likely been acceptable for most low maintenance or utility turfs. Visual estimates of turfgrass cover declined from June to August. Above average soil and air temperatures and lower than the 10 -year average precipitation occurred at the research site during that period, and the associated stress likely contributed to the turfgrass cover decline.

Results from this study indicate that buffalograss bur seeding rates influence turfgrass quality, shoot density, and cover of improved, turf-type cultivars, like 'Bowie'. 'Bowie' established most rapidly with seeding rates of 20 to $40 \mathrm{~g} \cdot \mathrm{m}^{-2}$. However, seeding rates $\geq 5$ $\mathrm{g} \cdot \mathrm{m}^{-2}$ established acceptable turfgrass quality and cover within the first growing season. With these results in mind, we would recommend seeding rates between 5 to $20 \mathrm{~g} \cdot \mathrm{m}^{-2}$ for establish- ment of most general turfgrass areas with a turf-type buffalograss. Higher bur seeding rates should be used when rapid establishment is desired or is needed to prevent soil erosion and potential weed encroachment.

\section{Literature cited}

Ahring, R.M. and G.W. Todd. 1977. The bur enclosure of the caryopses of buffalograss as a factor affecting germination. Agron. J. 69:15-17.

Beard, J.B. 1973. Turfgrass: Science and culture. Prentice Hall, Englewood Cliffs, N.J.

Beetle, A.A. 1950. Buffalograss-Native of the shortgrass plains. Agr. Expt. Sta., Univ. of Wyoming, Laramie. Bul. 293:1-3.

Duble, R.L. 1989. Southern turfgrasses: Their management and use. TexScape Inc., College Station, Texas.

Falkenberg, D.A. and J.D. Butler. 1981. Establishment of quality Buchlöe dactyloides turf. Proc. Intl. Turfgrass Res. Conf. Intl. Turfgrass Soc. 4:105-111.
Fry, J., W. Upham, and L. Leuthold. 1993. Seeding month and seed soaking affect buffalograss establishment. HortScience 28:902-903.

Fry, J.D. 1995. Establishing buffalograss. Golf Course Mgt. 63(4):58-60.

Gaitan-Gaitan, F., C.B. McKenney, and D.L. Auld. 1998. Effect of burs vs. caryopses and planting date on establishment of seeded buffalograss in the southern Great Plains. Crop Sci. 38:795-800.

Gaitan-Gaitan, F., C.B. McKenney, and D.L. Auld. 1999. Planting rate and caryopses effects on establishment of buffalograss on the southern Great Plains. J. Turfgrass Mgt. 3:1-11.

Harivandi, A. and L. Wu. 1995. Buffalograss-A promising drought resistant turf for California. Univ. of California Coop. Ext. 45:1-2.

Harivandi, A., L. Wu, C. Elmore, and W.L. Hagan. 1995. Buffalograss establishment studies. California Turfgrass Cult. 45:7-10.

Hartley, H.O. 1950. The maximum F-ratio as a shortcut test for heterogeneity of variance. Biometrika 37:308-312. 
Hauser, V.L. 1986. Emergence of several grasses from pregerminated seed and some soil water effects. Agron. J. 78:206-210.

Hickey, V.G., F.A. Miller, and M.C. Engelke. 1983. Buffalograss seed pretreatment germination. Texas Turfgrass Proc. PR 4169:126-128.

Keeley, S. and M.J. Fagerness. 2001. Buffalograss lawns. Kansas State Univ. Coop. Ext. Serv. Hort. Rpt. MF-658.

Launchbaugh, J.L. and C.E. Owensby. 1970. Seeding rate and first year stand relationships for six native grasses. J. Range Mgt. 23:414-417.

McCarty, L.B. 1995. Buffalograss-Description and use. Fact Sheet ENH116:8-9. Univ. of Florida Coop. Ext. Serv., Gainesville.

Quinn, J.A. 1987. Relationship between synaptosPermy and dioecy in the life history strategies of Buchloe dactyloides (Gramineae). Amer. J. Bot. 74:1167-1172.

Reeder, J.R. 1971. Notes on Mexican grasses. IX. Miscellaneous chromosome numbers. Brittonia 23:105-117.

Riordan, T.P., S.A. DeShazer, J.M. Johnson-Cicalese, and R.C. Shearman. 1993. An overview of breeding and development of buffalograss. Intl. Turfgrass Soc. Res. J. 7:816-822.

Riordan, T.P., P.G. Johnson, R.E. Gaussoin, and J.F. Svoboda. 1997. Seedling germination and establishment of Buchloe dactyloides caryopses vs. burs. Intl. Turfgrass Soc. Res. J. 8:749-756.

SAS Institute Inc. 1999. SAS /STAT user's guide. Release 8.0. SAS Inst., Cary, N.C.

Savage, D.A. 1934. Methods of re-establishing buffalograss on cultivated land in the Great Plains. U.S. Dept. Agr. Circ. $328: 20$

Stubbendieck, J., S.L. Hatch, and C.H. Butterfield. 1992. North American range plants. 5th ed. Univ. of Nebraska Press, Lincoln.

Wenger, L.E. 1940. Inflorescence variation in buffalograss, Buchloe dactyloides. J. Amer. Soc. Agron. 32:274-277.

Wenger, L.E. 1943. Buffalograss. Kansas Agr. Expt. Stn., Manhattan. Bul. 321:1-78.

Wu, L., D.R. Huff, and M.A. Harivandi. 1989. Buffalograss as a low maintenance turf. California Agr. 43(2):23-25. 